\title{
Qur'anic Pictures of the Universe: The Scriptural Foundation of Islamic Cosmology
}

\author{
Osman Bakar \\ Brunei, Darussalam: UBD Press; \\ Malaysia: Islamic Book Trust, 2016. 223 pages.
}

The Qur'an, the divinely revealed scripture of Islam, is not merely a book of commandments and prohibitions. Rather, the bulk of the Qur'an is related to faith: divinely communicated answers to existential questions about the origin of life and universe, the place of humankind in the cosmos, the relation between human, cosmos, and Creator, and more. The Islamic viewpoint regarding the nature, origin, and destiny of the universe in relation with the Creator forms the subject matter of Islamic cosmology, and of this book.

This book is part of the author's larger, yet-unpublished project on the scientific exegesis of the Qur'an. Maintaining that the Qur'an presents multiple pictures of the universe, instead of a single monolithic picture, the author has divided the main content of the book into seven chapters among which the last five elaborate such "pictures". These include the astronomical picture (chapter three), the architectural picture (chapter four), the picture of the cosmos as a divine kingdom (chapter five), the universe as a world of lights and darknesses (chapter six), and the human microcosm in the Qur'an (chapter seven). The first two chapters are concerned with Qur'anic definitions of the universe (chapter one) and an explanation for the multiplicity of Qur'anic pictures of the cosmos (chapter two). The book also includes an introduction, a bibliography (short but inclusive of the indispensable references), and a helpful index.

The author's method of arriving at a particular picture of the universe consists of a synthetic approach to the related verses dispersed in the different chapters of the Qur'an but unified thematically in a coherent way. The author himself argues that "the Qur'an features the Universe and its numerous pictures and images as one of its most attractive and interesting themes for human reflection and contemplation and scientific study" (4). Preferring the thematic and synthetic approach that is reflective of Islam's holistic epistemology to the "piecemeal exegesis of one or two so-called cosmic or creation verses" as usually inspired by the reductionist epistemology of modern science, the author has blended revealed metaphysical 
data with empirical scientific data to portray different harmonious images of the universe. The author's thematic engagement of the related Qur'anic verses and their synthesis into a coherent portrait of the Universe is intellectually stimulating and spiritually enlightening. In all this, the author has employed, as the central epistemological principle, the concept of "God's Self Disclosure" as propounded by the celebrated esoteric exegete of Islam, Ibn 'Arabi. According to this principle, the diversity in creation is actually reflective of God's numerous attributes. Hence, the multiple pictures of the universe.

In the first chapter of the book, the author elaborates Arabic terms (e.g., 'alamin, khalq, kawn) used in the Qur'an in relation to the cosmos. The author engages their linguistic (lexical/semantic) details, their frequency in the Quran, and the relation between their first and last occurrence in the Qur'anic text. The chapter is loaded with insightful information on these verses from linguistic, thematic, and theological-philosophical perspectives; he seeks to arrive at metaphysical conclusions from etymological discussions, bridging a simple science with a complex one.

In the following chapter, the author grapples with the cosmic unity in diversity, the multiple human visions of the universe despite its single divine vision, and the many subsystems of the universe (the angelic world, the human world, etc.) in order to justify the multiplicity of the Quranic pictures of the universe. In my humble opinion, this chapter is too short to satisfy this question; further, the reader may get confused regarding the relationship between the arguments and the conclusion. For example, while the author draws mainly on the Qur'anic word 'älamin-interestingly, a morphological plural-to substantiate the multiplicity of the images of the universe in the Qur'an, he himself accepts that the Qur'an uses this word to mean the entire cosmos (27).

The remaining five chapters of the book detail different Qur'anic terms and verses related to the cosmos, yielding the five "pictures" enumerated earlier. The discussion largely comprises thematic treatment of different related verses coupled with linguistic, theological/metaphysical, and scientific explanations. Yet what remains unanswered and intriguing is how far the Qur'anic pictures of the Universe correspond to modern scientific cosmology. What accounts for the Quranic style of allusive, cursory mention of such cosmic terms? Are there layers of meaning in these verses which obtain variously for different audiences? How did the earlier generations of Muslims-especially the Companions of the Prophet, peace and blessings upon him-understand such verses? In sum, the book is a welcome contri- 
bution to the genre of scientific Qur'anic exegesis in general, and Qur'anic cosmology in particular. In my humble opinion, it is a must read for the students and scholars of Islamic Studies as well as those of other related fields.

Gowhar Quadir Wani $\mathrm{PhD}$ candidate, Dept. of Islamic Studies, Aligarh Muslim University 